\title{
Discourse Network of a Public Issue Debate: A Study on Covid-19 Cases in Indonesia
}

\author{
ERIYANTO \\ Universitas Indonesia, Indonesia \\ DENNY JANUAR ALI \\ Indonesian Survey Circle, Indonesia
}

\begin{abstract}
This research is intended to answer the question of the discourses developed in association with Covid-19 management. Discourse in this regard is understood within the context of public policy, i.e. a set of concepts or ideas conveyed by actors to influence public policies. This study employed a discourse coalition theory. In addition, this study applied a discourse network analysis (DNA) method, combining discourse analysis (qualitative contents) and social network method. The DNA method maps any developing discourses on an issue (what) and also actors stating such discourses (who). The research was carried out for five months, starting from 17th November 2019 to 30th April 2020 and it included 1,123 statements of actors that were published in the media. The results of this study show that a coalition of discourse also occurs in health issues. The study reinforces the findings of Leifeld and Haunss (2011) on how actors attempt to present discourse to dominate the public conversation. This research shows the efforts of government actors, i.e. central government, regional governments, and the Ministry of Health, to conduct a coalition between two opposing discourses. The government efforts are not entirely successful. The government is also less successful in using communication channels and social media to form a single discourse.
\end{abstract}

Keywords: Discourse, discourse network analysis, public policies, media, discourse coalition.

\section{INTRODUCTION}

Covid-19 is one of the most dangerous pandemics in the last 50 years in addition to SARS (2003), H1N1 influenza (2009), Ebola (2014), and Zika (2016). The Covid-19 virus does not only present dangers to health but also affects social, cultural, political, and economic sectors. One of the key questions raised by many countries in the world is the steps to be taken by the governments to tackle the spread of the virus. The Covid-19 virus was first reported in Wuhan on $17^{\text {th }}$ November 2019. Reports on the virus discovery in several countries have been submitted since the end of January 2020. In reality, countries in the world had enough time to prepare themselves to prevent the spread of the virus. However, harsh and drastic steps have other impacts, such as the cessation of economic activities. It explains why many countries missed the moment to take serious measures. Harsh measures were only taken when the virus has spread widely in the community (Romel et al., 2020).

In Indonesia, the first positive case was reported on 2nd March 2020. However, strict measures were only implemented by the government of Indonesia on 10th April 2020 in the form of large-scale social restriction (PSBB/Pembatasan Sosial Berskala Besar). For 5 consecutive months (November 2019-April 2020), the government of Indonesia was confused about choosing the appropriate policy. During those five months as well, a public debate occurred in Indonesia regarding the steps that should be taken by the government. The debate transpired in many spaces, starting from news media, television talk 
shows, social media posts, to seminars and scientific forums. The debate involved many actors, such as medical doctors, epidemiologists, government officials, and citizens.

This research applied the discourse coalition theory by Hajer $(1993,1995,2002)$. This theory assumes that public policymakers face various discourses and discourse rivalry from various actors. Policymaking is an open arena for many actors. Actors attempt to have their discourses used by the policymakers. In the context of the Covid-19 management policy, the actors mutually proposed discourses on the handling of the Covid-19 cases. The discourses were delivered in various forms, starting from social media posts to media interviews. One method used to map discourses related to public policy and discourse competition among the actors is Discourse Network Analysis (Leifeld \& Haunss, 2010; Leifeld, 2017).

Discourse network is frequently used to describe the relationship between discourse and public policy. Policies made by the government do not exist in a vacuum space, but they exist in particular contexts. There are many actors in society and each actor has a specific position related to the public policy. The actors submit proposals through discourses to influence and emphasize to the public that their proposals are the best. The policymakers stand among various discourses and competition among actors. The discourse network is useful to map the emerging discourses, actors who propose the discourses, and connection (network) of such discourses.

The discourse networks have been studied extensively in several studies. The topic raised is the political issue, such as studies carried out by Fisher et al. (2013), Leifeld (2013), Steinfeld (2016), Muller (2015), Heaney and Leifeld (2018) and Wallaschek et al. (2020). Another topic is a debate on the issue of environment and change in the advertisement such as studies conducted by Yun et al. (2014) in South Korea, Wagner \& Payne (2017) in Ireland, Kukkonen and Ylä-Anttila (2020) in Finland, Ghinoi and Steiner (2020) in Italy, and Broadbent and Vaughter (2014). Other researches describing the discourse networks examine a debate about development megaproject in Germany (Nagel \& Satoh, 2018); software rights in the European countries (Leifeld \& Haunss, 2012); state's access to block broadcasts in Germany and France (Berindl, 2013); soft drink industry in the UK (Buckton et al., 2019); agricultural policies in Brazil (Ghinoi et al., 2018); and alcohol debate in the UK (Fergie et al., 2019).

This research aims to answer the following question: what discourses are developing in association with Covid-19 management? Discourse in this regard is understood within the context of public policy, i.e. a set of concepts or ideas conveyed by actors to influence public policies. There are many actors in the issue of Covid-19 management, from central government officials, epidemiologists, to the public. Each actor had their discourses on what policies should be taken by the government. The actors attempted to influence policies by delivering their discourses through a variety of media, such as media interviews, social media posts, and others. Studies on discourse network are rarely applied to map public debates on the issue of health. This research completes previous studies on discourse network by describing dominant discourses, actors of each discourse, networks of the actors and discourses, as well as compatibility and conflict of the discourses on health issue (Covid-19).

\section{Discourse}

The concept of discourse is used in many fields. In general, discourse is the practice of using languages in different social lives, such as medical discourse, political discourse, and many others (Jorgensen \& Philips, 2002; Waagsaether \& Scott, 2016). Discourse is related to how 
humans understand the world and aspects of the world (Jorgensen \& Phillips, 2002). This paper uses a definition of discourse proposed by Hajer $(1993,1995,2002)$. According to Hajer (1993, p.63; 1995, p.44; 2002, p.61), discourse is a set of ideas, conceptions, concepts and categorizations produced, reproduced and changed in certain practices, through which meaning is given to physical and social reality.

Based on the definition proposed by Hajer, there are several elements of a discourse. First, discourse contains certain ideas, thoughts or concepts, e.g. issues regarding the handling of the Covid-19 virus. Issues can be observed in a variety of discourse, starting from medicine, economics, environment, to religion. Each discourse contains certain ideas and thoughts. Second, discourse is produced, reproduced, and changed by social actors. Discourse is not something falling from the sky. On the contrary, discourse is produced by certain actors. Third, discourse is constructed by actors. The same event (Covid-19 virus) can be constructed in different ways. Actors have a particular interest in how reality is constructed. Fourth, discourse is bound to certain social contexts.

\section{Discourse and Public Policy}

How can discourse influence public policy? Hajer (1995) introduces a theory known as discourse coalition theory. In contrast to many other experts observing policymaking from institutions and political process, Hajer observes the policy process as a discourse battle. In public policy, some actors have an interest in an issue. The actors then construct messages according to their position. This is carried out by actors by reproducing their discursive position (what they stand for) in the context of controversy (Hajer, 1995, p.54). Actors influence public policies by producing discourse with an aim that the discourse is accepted by wider audiences.

Each actor provides an argument to convince the public that what they are saying is true. The argumentation process takes place in discussions when the actors position themselves and debate on certain controversial issues. Debates related to an issue can thus be seen as "political" when one actor or group of actors attempting to make their claim dominant. Thus, their proposed discourse will dominate decision-making (Hajer, 1995). This effort is taken by the actors by making a legitimacy claim to knowledge as the base of their discourse. The actors fight each other in making claims so that their discourse is more acceptable to the public and policymakers. The fight is carried out through statements in the media, posts on social media, interviews in television talk shows, and others.

The efforts to make the discourse proposed by the actors more acceptable are performed through language. The actors do not only provide a statement but also use language to persuade the public that the discourse presented by the actors is the best discourse compared to others. This is carried out by the actors by, for example, creating storylines, metaphors, words or phrases that can provoke public emotions (Linder, 1995; Olick \& Levy, 1997). An actor proposes a discourse and other actors also present a different discourse. Each actor presents the discourse complete with particular moral and knowledge argument and claim.

The result of such discourse competition is the emergence of dominant discourse, dominating the public discussion. Hajer (1993) mentions that the success of discourse (a discourse becomes dominant) is often not because the discourse is the best but due to the success of the actors in packaging and constructing messages to be received by the public. The actors build storylines, vocabularies, and metaphors that can provoke public support. The 
final result of this dominant discourse is the discourse institutionalization. It occurs when a specific discourse is strengthened into public policy (Hajer, 1995).

Hajer's concept of message construction by actors is similar to Benford and Snow's (2000) concept of a discursive process in social movements. According to Benford and Snow, actors of social movements take initiative to encourage the public to support their movements. Thus, the public does not only support their movements but also takes active roles in such movements. This discursive process involves two strategies, namely frame articulation and frame amplification. Frame articulation is a process attempting to connect the experience of an individual with the experience of others to connect them with the issues fought for by social movements. Meanwhile, frame amplification provides emotional ambience in a message by using words, symbols, and others.

\section{Discourse Network}

The discourse coalition theory observes that public policy is inseparable from discourses. The policymakers use publicly dominant and developing discourses as a basis to make decisions to convince that the policies made are valid (legitimate) and supported by wider society. Such policymaking is therefore considered as a battle among actors who have different position and interest. The actors will establish and construct the event and spread it to the audiences to encourage them to participate and ensure that the proposed concept and discourse is the most legitimate one.

Each actor has a different discourse on an issue, yet at one time, these discourses can be interconnected. The actors who want to make their discourse dominant will adjust their discourse or merge it with other discourses. Hajer (1995) calls this phenomenon as a discourse coalition. This term is similar to coalitions in the politics, where actors or political parties, in an attempt to win the election, unite (form a coalition) with other political parties by establishing a major coalition. Discourse, according to Hajer (1995), is also similar. The actors may adjust a discourse to other discourses to ensure that the idea can prevail. The discourse coalition occurs when the actors realize that many discourses emerge in the public and confuse the audiences. Therefore, such discourses have a low possibility to become dominant.

This discourse network concept is similar to the strategic process concept by Benford and Snow (2000) in the social movement theory. According to Benford and Snow, there are possibly many actors in a social movement. The high number of actors with their respective interest and claim may render it difficult to obtain public support because the issue is separated into smaller fragments. An initiative that may be taken by the actors of the social movement is building a frame bridging. This process is carried out by connecting two or more different concepts. Through this process, the actors leave their proposed concept for a greater purpose.

\section{Discourse Conflict}

In the discourse competition, the actors can adjust their discourse with other discourses to influence public policies. This process can result in a discourse coalition. Alternatively, discourse cannot be combined with other discourses. In this condition, there is a conflict of policy discourse in which two dominant discourses are conflicting with each other.

According to Schon and Rein (1994), policy conflicts can be divided into two categories, namely simple and controversial conflicts. A simple conflict is a conflict that is easily resolved by the actors. The policymakers can immediately adjust or change existing 
policy choices. Meanwhile, a controversial conflict is a conflict that is difficult to resolve because the conflict is related to values, beliefs, ideologies and others. The examples of controversial policy conflicts are those on abortion, euthanasia, nuclear energy, global warming, and LGBT rights. In the debate regarding this policy, each actor has an opposing position that is difficult to compromise (Muller, 2015). The position of simple and controversial conflicts takes a continuum form from the lowest to the highest.

This policy conflict can be applied to discourse conflicts (see Muller, 2015). In the public debate related to an issue, there are simple discourse conflicts and several controversial ones. In simple conflicts, discourse differences are not severe. The actors can change or adjust the discourses. Meanwhile, in controversial discourses, discourse conflicts are highly harsh. The actors cannot change the existing discourses. As a result, conflicting discourses related to an issue will emerge.

\section{METHODS}

This research applied discourse network analysis (DNA) method. This method is developed by Philip Leifeld, a combination of discourse analysis (qualitative contents) and social networks method. It also settles the weaknesses of the two methods (see Leifeld \& Haunss, 2010). The content/discourse analysis only maps the content of an issue, while the network analysis focuses on actors and networks among the dominant actors in the discussion of an issue. The DNA method maps any developing discourses on an issue (what) and actors proposing the discourses (who). In this research, the DNA was applied to map any developing discourses related to the Covid-19 management and dominant actors (persons or organizations) proposing the discourses.

DNA describes the relationship or network among developing discourses (referred to as concepts) and actors. Figure 1 provides a general overview of the DNA method. The actors are symbolized by circles while discourses (concepts) are symbolized by squares. DNA maps the relationship between the actors and concepts. For instance, is there any relationship between government officials and non-governmental organizations? Or is there any relationship between discourses on the local quarantine (lockdown) and discourses on a healthy lifestyle? etc. DNA also maps the relationship between the actors and concepts, referred to as an affiliate network. Who are the actors (persons or organizations) proposing the concepts (discourses)? As DNA observes the networks between the concepts (discourses) and actors, the results from DNA can be later used to perceive the congruence or conflict of the networks (Leifeld, 2017). The networks are considered to be congruent supposing the actors offer the same concept. Instead, it is referred to as a conflict supposing the actors suggest a discourse (concept) that is conflicting with an issue. 
actors concepts
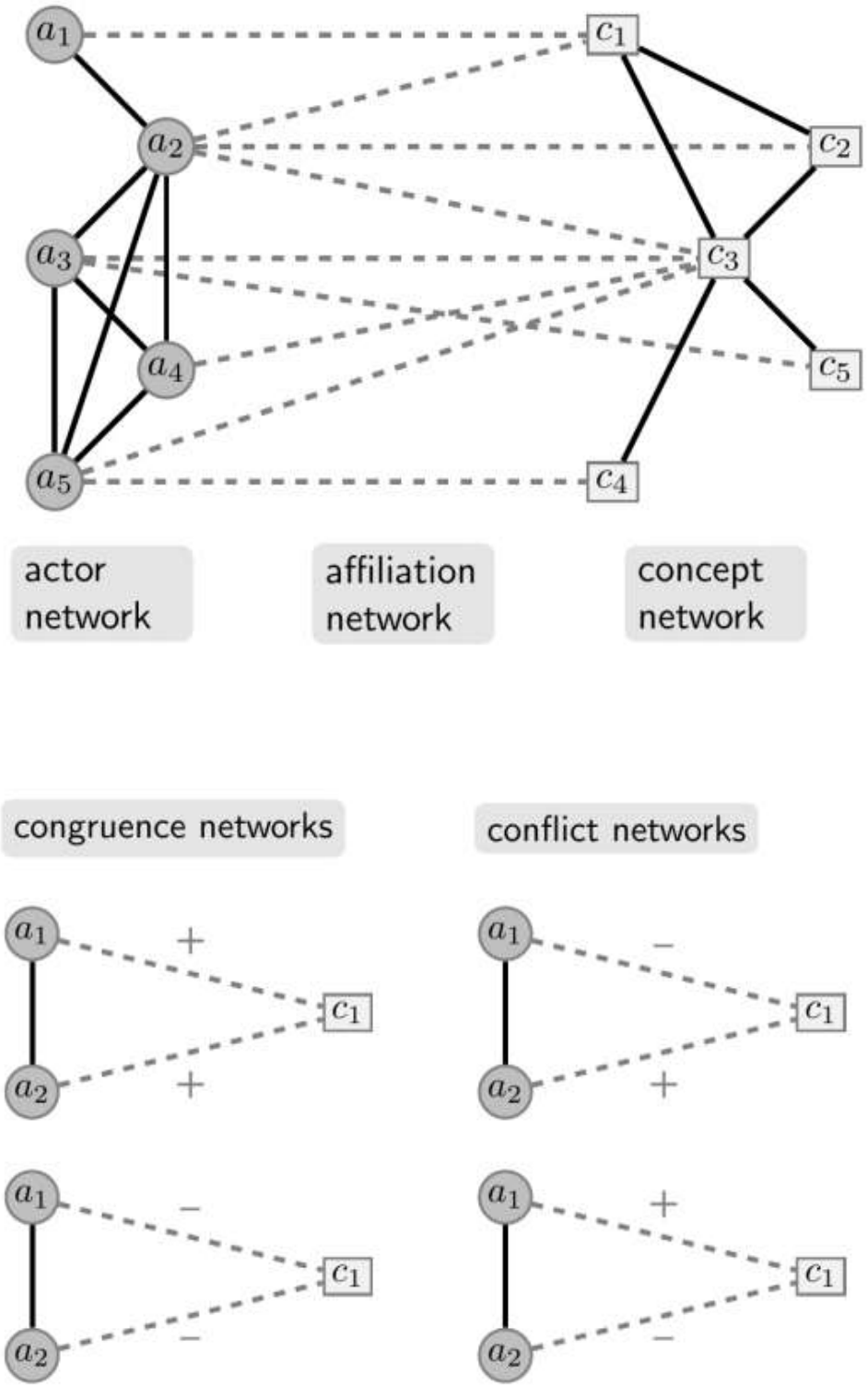

Figure 1: Discourse Network Analysis (DNA) Overview Source: Leifeld (2017)

In this study, the DNA method was applied to describe the congruence and conflict of discourses related to the issue of Covid-19 virus management. The DNA research process was carried out by taking steps suggested by Leifeld and Haunss (2010, 2012), and Leifeld (2017). The first step was collecting the material. The unit of analysis of the DNA research is statements from the actors. These statements were obtained from direct comments, news, social media posts, and many more. To collect statements from the actors, the researcher used online media, i.e. Detik.com and Kompas.com. In this research, discourses delivered by the actors are limited to discourses released by online media. The actors might propose 
discourses through social media posts, but provided that the media quoted and released the statements of the actors, such discourses were part of the study.

The researcher collected all news in both online media by applying the keywords of "Corona" or "Covid-19" for 5 consecutive months (17th November 2019 - 30th April 2020). The total of 5,462 news articles was collected in this phase. The news was then filtered by criteria whether it contained any statements from the actors concerning solutions to handle the Covid-19 virus. The news on conditions of victims as well as the preparedness of hospitals and medical personnel were not included in the analysis because such news does not mention any statements on solutions to handle the virus.

According to this selection, news relevant to the research purpose amounted to 1,328 articles, 607 of which were news articles from Detik.com and the remaining 721 of which were taken from Kompas.com. The relevant news was then identified for statements. One news article may have more than 1 actor (such as interviewed sources). There were a total of 3,320 statements from both newspaper outlets.

Then, the researcher checked the statements of the actors on Detik.com and Kompas.com for any similarities. On the same day, Detik.com and Kompas.com may release similar statements from the same officials. In this case, one of the statements in the online media is deleted, since the unit of analysis in DNA is statements rather than the number of news articles. The online media news is one of the means utilized by the researcher to find any statements showing the actors and discourses (concepts). The outcome of this process is 1,123 statements to be analysed.

The second phase was the identification of discourses (concepts) and actors. The statements collected were categorized or grouped based on the discourses (concepts) and actors. Discourses (concepts) were grouped into 12 groups, starting from isolation to local quarantine (lockdown). The same concepts were grouped into one. For example, the quarantine and lockdown refer to the same definition, even though the words used are different --- to limit all activities and movement of the community in one area. In the meantime, the actors were grouped into 16 categories, from government officials to international actors. The researcher took samples of $10 \%$ out of the total population to test the intercoder reliability. All categories are reliable because the reliability coefficient is above 0.7 . The reliability coefficient above 0.7 (70\%) shows that the measurement tools are reliable (Riffe et al., 2019).

Third, all statements (total 1,123 statements) were inputted into DNA Analyzer software version 2.0 (Leifeld et al., 2019). Fourth, following the completion of input, the data were processed using VISONE software (Brandes \& Wagner, 2004). This software maps the actors and concepts in the networks. In addition to the network visualization, this software also presents data on the network description, including degree, betweenness, closeness, and eigenvector. The degree shows popularity. Closeness refers to nearness. Betweenness measures how far the actors or concepts are connected to other actors or concepts (Golbeck, 2013).

\section{FINDINGS}

This study reviewed developing discourses and the actors of the discourses for 5 consecutive months (17th November 2019 - 20th April 2020). As referred to by Leifeld and Haunss (2010, 2012), a discourse on an issue is dynamic. The actors involved and the developing discourses heavily depend on the recent situational context. Based on this argument, a discussion on the 
discourse network of the Covid-19 virus management was divided into 4 phases, i.e. phase 1 (17th November - 2nd March 2020), phase 2 (3rd - 17th March 2020), phase 3 (18th March -10th April 2020), and phase 4 (11th - 30th April 2020). The dominant actors, discourses and networks between them are different in each phase.

In the first phase, discussions about the virus were still limited. This topic was only discussed among government officials, the Ministry of Health, as well as international experts and epidemiologists. The discourses developing in this first phase generally did not consider this virus as a dangerous virus. The discourses proposed were an appeal for citizens not to panic or afraid nor do anything because this virus was similar to a common cold that would later be cured providing that people had a good immune system, as stated by the government officials and the Ministry of Health. Therefore, the government and the health department also presented a discourse for the community to strengthen their immunity.

The discourse proposed by the officials of the Ministry of Health was indeed not merely a single discourse. Other actors (such as epidemiologists, politicians or international experts) delivered other discourses on the need for vigilance in Indonesia. Figure 2 shows the congruence and conflict of discourses. The figure shows the modularity or cluster formed from the discourses debated about the Covid-19 cases in the first phase. Observed from the figure, it can be seen that government officials and the officials of the Ministry of Health belong in one group of actors, while the other group consists of epidemiologists as well as political and international experts. Both groups proposed different (conflicting) solutions related to the handling of the Covid-19 virus. These data describe that the government officials and the Department of Health initially chose a solution opposing the solution delivered by the epidemiologists and international communities on the need for vigilance related to Covid-19.

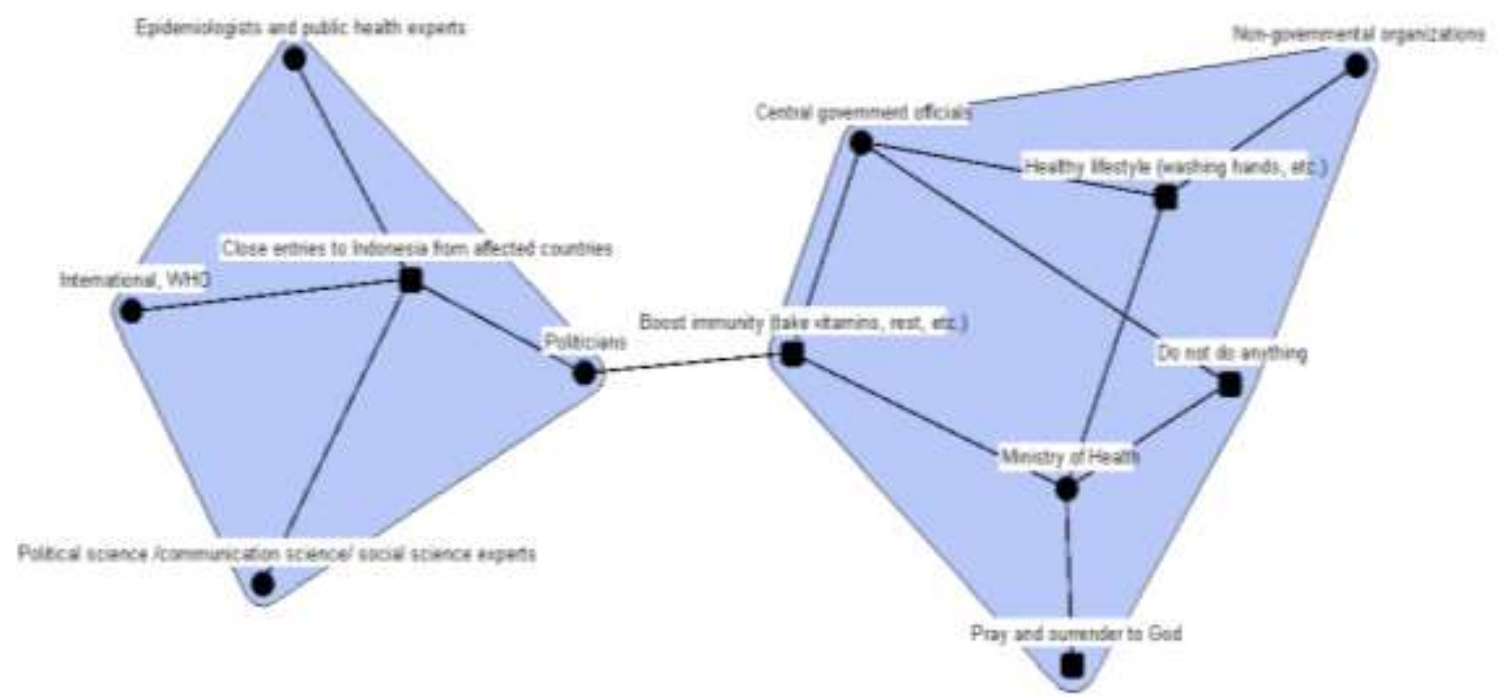

Figure 2: Compatibility and Conflict of the Discourses and Actors of Covid-19 Phase 1 Issue Note: Modularity uses an algorithm from Girvan-Newman

The second phase of the Covid-19 case was conducted from 3rd March (following the discovery of the first positive case) to 17th March (the establishment of the Covid-19 Task Force). Debates on the solutions related to virus management were far developed in this phase rather than in the first phase. In this second phase, the public was provided with an awareness that the virus had arrived in Indonesia and become a serious threat supposing it 
was not handled well. There were 4 dominant discourses developing in this phase, i.e. lockdown (totally closing an area for both movement and activities of the community), selfisolation (separating healthy people from those positive/infected with the virus), massive and rapid tests to know the number of the virus spread, and boosting the immunity. The discourse on the need for lockdown in Indonesia was proposed by NGO (non-governmental organization), doctors/hospitals, politicians, and international organizations. The discourse on self-isolation was delivered by public policy experts, hospitals/doctors, and the Ministry of Health. The discourse on massive and rapid tests was stated by epidemiologists, international organizations, and hospitals. Meanwhile, the discourse on boosting immunity was proposed by the Ministry of Health, central government officials, hospitals, and politicians.

This second phase was marked by numerous discourses on suggestions for Covid-19 management. The actors proposing the discourses on virus handling were also more varied. They were not only dominated by government officials and the Ministry of Health. Media also started to publish comments from public members and public/religious figures. It made this issue no longer an elite issue. Figure 3 shows the grouping of discourses and actors proposing the discourses, distributed into 4 groups (clusters). Government officials and the Ministry of Health belong into one cluster and face other clusters, i.e. NGO and epidemiologists. Two other clusters are public members and public figures.

Interestingly, the discourse delivered by the government and Ministry of Health seemed to contradict (conflict) with the discourse described by the epidemiologists and civil organizations. There are 3 actors serving as the bridge (intermediary), namely public policy experts, hospitals, and politicians. It is marked with the high value of betweenness of these three actors (Table 1). They did not only approve the discourse provided by the government and Ministry of Health but also consented to the discourse proposed by the NGO and epidemiologists. 


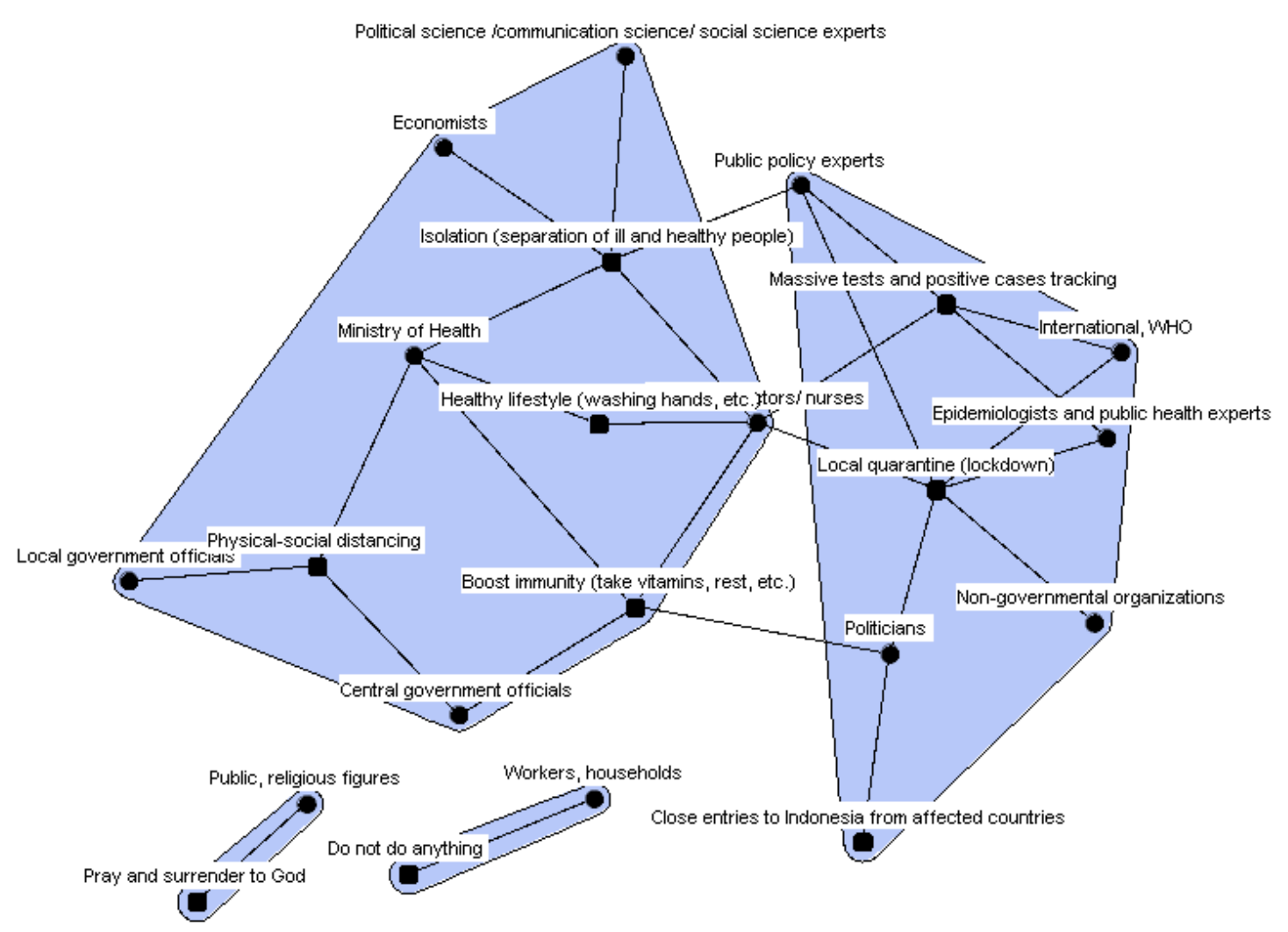

Figure 3: Compatibility and Conflict of the Discourses and Actors of Covid-19 Phase 2 Issue Note: Modularity uses an algorithm from Girvan-Newman

Discourses on the Covid-19 management were heatedly discussed in the third phase. This phase began with the establishment of the Covid-19 task force on 18th March 2020. The government and task force in this phase were urged by various groups to take stricter measures to restrain the spread of the virus. In this period, many predictions emerged. Predictions from various researchers asserted that the number of cases and deaths would be high supposing the government did not take any strict and harsh measures.

Numerous scenarios concerning the solutions to virus management were developing. These scenarios were taken from the best practices of various countries that have succeeded in restraining the spread of the virus. The first scenario was a total restriction on the movement and activities of the community (lockdown). The second scenario was massive tests and tracking of people indicated to be virus-positive. The third scenario was isolation to separate healthy people from people who have been positively confirmed to contract the virus. The fourth scenario was physical distancing to prevent the virus from spreading easily.

Figure 4 shows a complete map of discourses and actors in the third phase. Each actor competed to ensure that their discourse obtained more support. The actors provided statements in media and delivered their opinion in talk shows or interviews. Each actor attempted to make their discourse more preferable by the public. The third phase was marked by a harsh discourse competition among the actors. As shown in the figure, there are two major groups (cluster). The first cluster is epidemiologists, civil organizations, public policy experts, international organizations, and politicians. This group suggested a harsh measure to manage Covid-19, such as local quarantine and massive tests. Another group is the Ministry of Health, central government officials, local government officials, BNPB, economists, businesses, SMEs, and the public. This group suggested a more moderate 
discourse on virus handling, such as isolation, physical distancing, boosting immunity, and a healthy lifestyle. This figure shows the conflict among the public regarding measures to be taken by the government to manage the spread of the virus. It can be seen that local government officials, hospitals, and public policy experts are the bridge for those two groups. These three actors have a high value of betweenness than other actors (Table 1). It means these three actors accept the discourses of the two groups, both harsh and moderate measures.

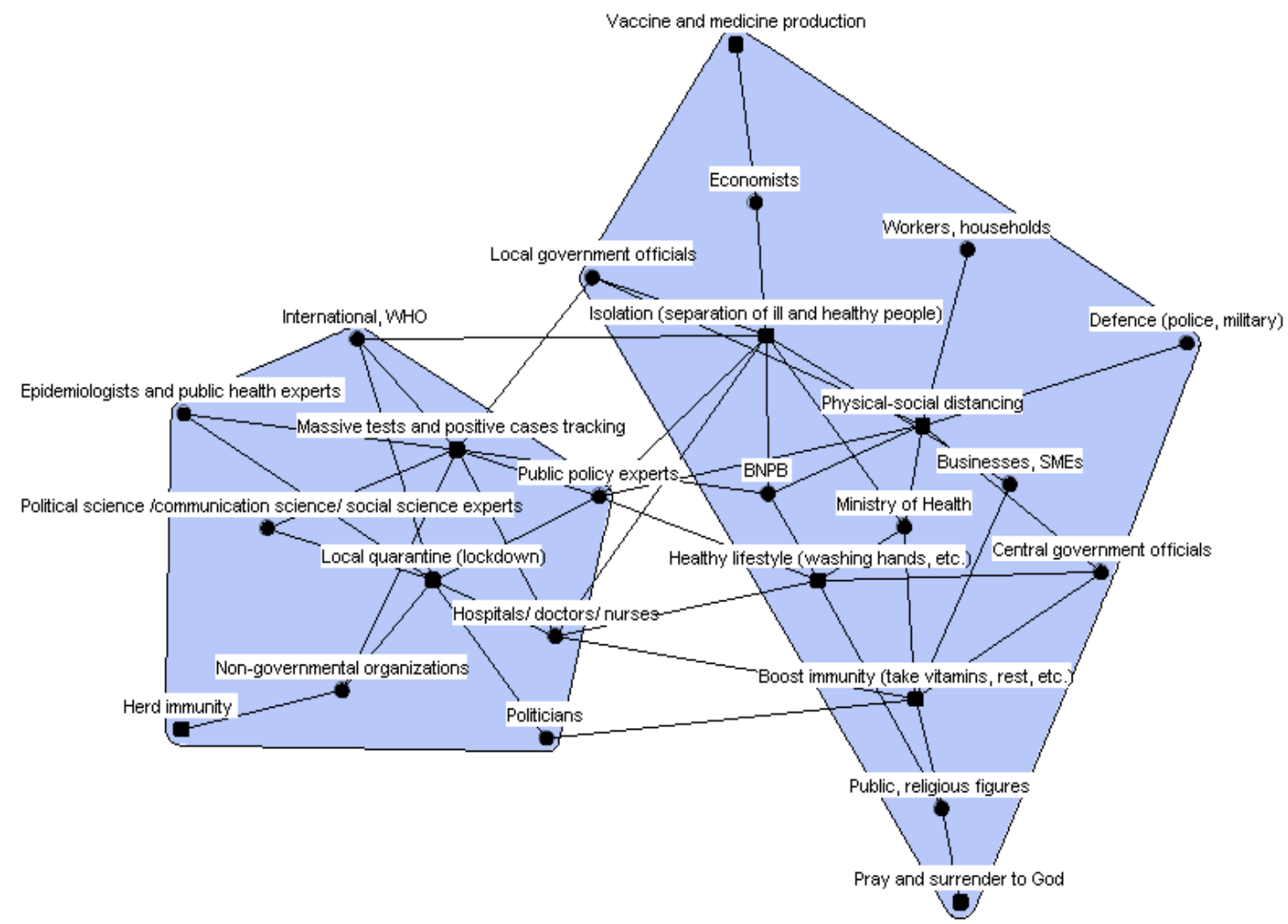

Figure 4: Compatibility and Conflict of the Discourse and Actors of Covid-19 Phase 3 Issue Note: Modularity uses an algorithm from Girvan-Newman

The third phase ended after President Joko Widodo officially decided for PSBB (LargeScale Social Restriction) on 10th April 2020. Remarkably, this policy had never been discussed in the third phase. This policy seemed to compromise the discourse that wanted Indonesia to have a stricter attitude to handle the crisis (local quarantine, massive tests) and one that suggested a more moderate solution (isolation, physical distancing, and healthy lifestyle). By issuing the PSBB policy, the government did not prohibit people's activities. Instead, the policy only restricted the people's activities (such as closing shopping centres, offices, and schools/universities).

Figure 5 shows the network of actors and discourses (concepts) that has developed from 10th to 30th April 2020. Even though the government had taken an official policy of PSBB, this policy seemed unsatisfactory for many parties. It can be seen from the discourse split and conflict in Figure 5. This figure shows that there are two major groups (clusters) of discourses and actors, similar to the third phase. The first group consists of public policy 
experts, epidemiologists, politicians, and civil organizations. They started a discourse on local quarantine (lockdown) and massive tests. According to this group, the policy taken by the government (PSBB) had not been proven effective in restricting the activities of the community. The second group consists of central government officials, the Ministry of Health, hospitals, businesses/SMEs, and the public. This group approved the policy choice of the government. According to this group, the restriction policy (PSBB) was the most reasonable policy for the current condition of Indonesia. The argument frequently delivered was the success of the strict policy choice (local quarantine) in Indonesia was not guaranteed even though it had been proven to be effective in several countries. Local quarantine needed the discipline of the public as well as the sufficiency and preparedness of economic resources (food and budget).

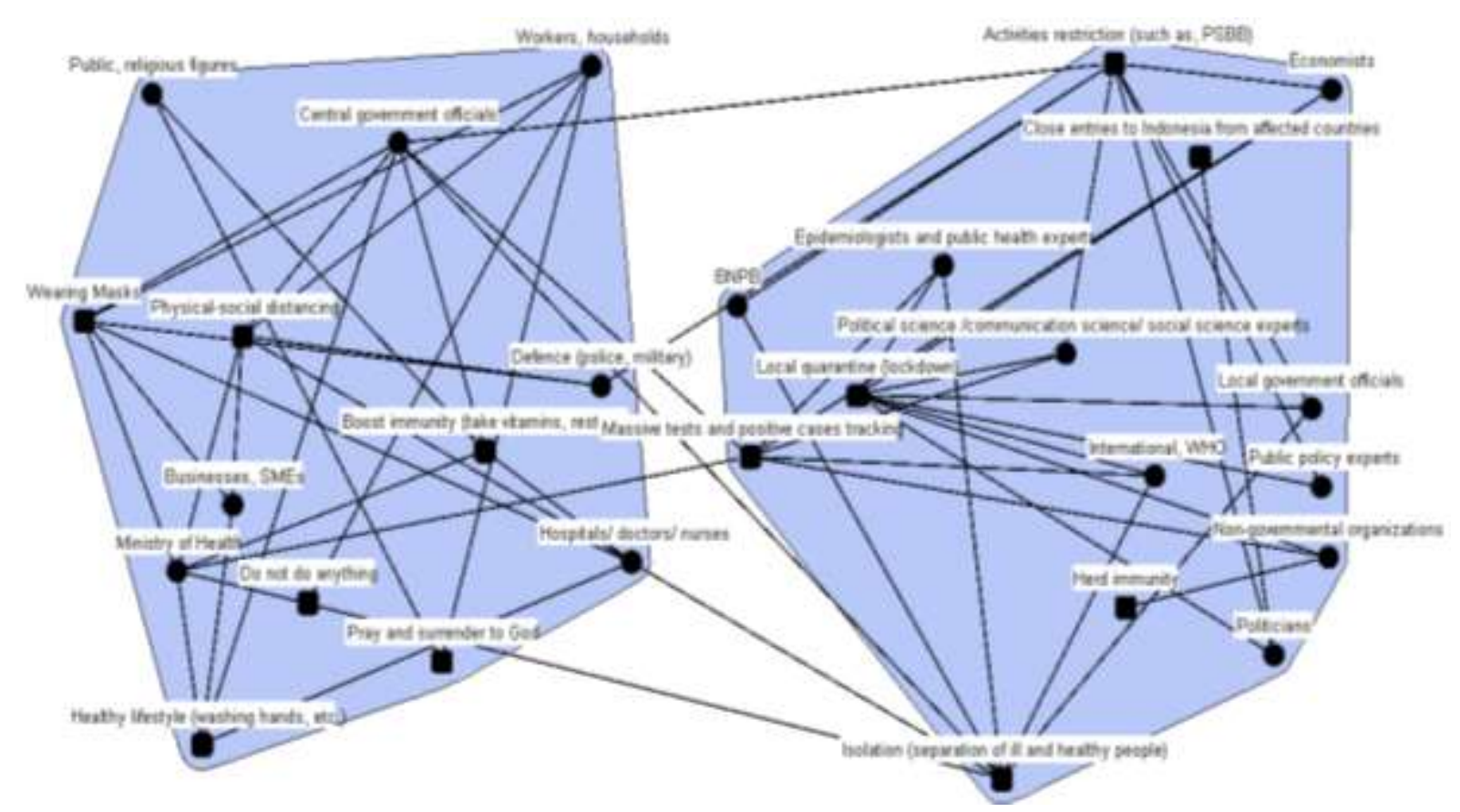

Figure 5: Compatibility and Conflict of the Discourses and Actors of Covid-19 Phase 4 Issue Note: Modularity uses an algorithm from Girvan-Newman

The following table shows the description of the discourses of Covid-19 virus management in phase 1 to phase 4. As shown in the table, the most dominant discourse in phase 1 is that it is not necessary to fear this virus. What people need to do is to strengthen their immunity. This discourse has the highest degree. Meanwhile, in the view of the actors, the Ministry of Health is the most dominant actor, characterized by the highest level (degree). In phase 2, the most dominant discourse is that it is not necessary to fear this virus. This discourse has the highest degree. Meanwhile, in the view of the actors, the Ministry of Health is the most dominant actor, characterized by the highest level (degree).

In phase 3, the dominant and developing discourses are local quarantine (lockdown), massive tests and tracking positive cases, as well as boosting immune (taking vitamins, exercising, etc.). The dominant actors are hospitals, public policy experts, and the Ministry of Health. Meanwhile, in phase 4 , there are 4 dominant concepts, i.e. physical distancing, isolation, local quarantine (lockdown), and massive tests. The dominant actors are the Ministry of Health, BNPB, hospitals, and public policy experts. These four actors have the highest degree than other actors. 
Jurnal Komunikasi:

Malaysian Journal of Communication

Jilid 36(3) 2020: 209-227

Table 1: Description on the Popularity of Actors and Issue Concept

\begin{tabular}{|c|c|c|c|c|c|c|c|c|c|c|c|c|c|}
\hline \multirow[b]{2}{*}{ Name } & \multirow[b]{2}{*}{ Variable } & \multicolumn{4}{|c|}{ Degree (\%) } & \multicolumn{4}{|c|}{ Closeness (\%) } & \multicolumn{4}{|c|}{ Betweenness (\%) } \\
\hline & & Phase 1 & Phase 2 & Phase 3 & Phase 4 & Phase 1 & Phase 2 & Phase 3 & Phase 4 & Phase 1 & Phase 2 & Phase 3 & Phase 4 \\
\hline Isolation (separation of ill and & & - & 8.93 & 8.89 & & - & 6.47 & 4.85 & & - & 15.83 & 13.95 & \\
\hline healthy people) & Concept & & & & 6.36 & & & & 4.09 & & & & 7.26 \\
\hline Massive tests and positive & Concept & - & 7.14 & 8.89 & & - & 5.57 & 4.85 & & - & 4.41 & 11.03 & \\
\hline cases tracking & & & & & 6.36 & & & & 4.22 & & & & 9.65 \\
\hline Local quarantine (lockdown) & Concept & - & 10.71 & 7.78 & 7.27 & - & 6.47 & 4.67 & 3.45 & - & 15.96 & 8.40 & 5.96 \\
\hline Activities restriction (such as & Concept & - & - & - & & - & - & - & & - & - & - & \\
\hline PSBB) & & & & & 7.27 & & & & 4.36 & & & & 12.28 \\
\hline Doing nothing & Concept & 7.69 & 1.79 & - & 0.91 & 7.82 & 0.83 & - & 2.42 & 0.52 & 0.00 & - & 0.00 \\
\hline Praying and surrendering to & Concept & & 1.79 & 1.11 & & & 0.83 & 2.68 & & & 0.00 & 0.00 & \\
\hline God & & 3.85 & & & 1.82 & 7.37 & & & 2.52 & 0.00 & & & 0.47 \\
\hline Herd immunity & Concept & - & & 1.11 & 0.91 & - & & 2.74 & 2.57 & - & & 0.00 & 0.00 \\
\hline Physical-social distancing & Concept & - & 5.36 & 7.78 & 5.45 & - & 4.69 & 4.51 & 4.09 & - & 6.50 & 10.82 & 6.44 \\
\hline Wearing Masks & Concept & - & - & - & 5.45 & - & - & 0 & 4.09 & - & - & - & 6.44 \\
\hline Healthy lifestyle (washing & Concept & & 5.36 & 6.67 & & & 5.84 & 4.51 & & & 3.60 & 6.85 & \\
\hline hands, etc.) & & 11.54 & & & 3.64 & 8.33 & & & 3.64 & 8.40 & & & 1.13 \\
\hline Boosting immunity (taking & Concept & & 7.14 & 6.67 & & & 6.47 & 4.51 & & & 10.19 & 7.02 & \\
\hline vitamins, resting, etc.) & & 15.38 & & & 3.64 & 8.90 & & & 3.74 & 21.26 & & & 4.33 \\
\hline Closing entries to Indonesia & Concept & & 1.79 & - & & & 4.20 & & & & 0.00 & - & \\
\hline from affected countries & & 11.54 & & & 0.91 & 11.22 & & & 2.62 & 24.15 & & & 0.00 \\
\hline Vaccine and medicine & Concept & & & 1.11 & & & & 2.63 & & & & 0.00 & \\
\hline production & & & & & - & & & & - & & & & - \\
\hline Central government officials & Organization & & 5.36 & 3.33 & & & & 3.88 & & & & 1.49 & \\
\hline $\begin{array}{l}\text { (Minister, Director General, } \\
\text { etc.) }\end{array}$ & & 11.54 & & & 6.36 & 9.56 & 5.09 & & 5.04 & 7.87 & 3.52 & & 12.83 \\
\hline Local government officials & Organization & - & 1.79 & 3.33 & & - & & 4.43 & & - & & 2.30 & \\
\hline (Regents, Governors, etc.) & & & & & 2.73 & & 3.57 & & 3.74 & & 0.00 & & 1.15 \\
\hline BNPB & Organization & - & - & 4.44 & 1.82 & - & - & 4.95 & 3.45 & - & - & 3.95 & 0.31 \\
\hline Politicians (Members of the & Organization & & & 2.22 & & & & 3.88 & & & 8.10 & 1.00 & \\
\hline $\begin{array}{l}\text { People's House of } \\
\text { Representatives/Local }\end{array}$ & & & & & & & & & & & & & \\
\hline People's House of & & & & & & & & & & & & & \\
\hline $\begin{array}{l}\text { Representatives, political } \\
\text { party members) }\end{array}$ & & 7.69 & 5.36 & & 2.73 & 10.32 & 5.84 & & 3.54 & 22.05 & & & 4.11 \\
\hline Hospitals/doctors/nurses & Organization & - & 8.93 & 5.56 & 4.55 & & 7.25 & 4.95 & 3.74 & - & 15.98 & 6.54 & 2.52 \\
\hline
\end{tabular}

E-ISSN: 2289-1528

https://doi.org/10.17576/JKMJC-2020-3603-13 
Discourse Network of a Public Issue Debate: A Study on Covid-19 Cases in Indonesia

Eriyanto \& Denny Januar Ali

\begin{tabular}{|c|c|c|c|c|c|c|c|c|c|c|c|c|c|}
\hline \multirow[b]{2}{*}{ Name } & \multirow[b]{2}{*}{ Variable } & \multicolumn{4}{|c|}{ Degree (\%) } & \multicolumn{4}{|c|}{ Closeness (\%) } & \multicolumn{4}{|c|}{ Betweenness (\%) } \\
\hline & & Phase 1 & Phase 2 & Phase 3 & Phase 4 & Phase 1 & Phase 2 & Phase 3 & Phase 4 & Phase 1 & Phase 2 & Phase 3 & Phase 4 \\
\hline Public policy experts & Organization & - & 5.36 & 5.56 & 1.82 & & 6.14 & 5.37 & 3.45 & - & 4.73 & 7.37 & 0.29 \\
\hline $\begin{array}{l}\text { Political } \\
\text { science/communication }\end{array}$ & Organization & & & 2.22 & & & & 3.55 & & & & & \\
\hline science/social science experts & & 3.85 & 1.79 & & 2.73 & 6.62 & 4.52 & & 3.64 & 0.00 & 0.00 & 0.12 & 0.85 \\
\hline Civilians' organizations, non- & Organization & & 1.79 & 3.33 & & & & 3.66 & & & 0.00 & 4.54 & \\
\hline governmental organizations & & 3.85 & & & 2.73 & 6.30 & 4.52 & & 3.45 & 0.00 & & & 4.07 \\
\hline International, WHO & Organization & 3.85 & 3.57 & 3.33 & 2.73 & 6.62 & 4.69 & 4.14 & 3.64 & 0.00 & 0.34 & 1.48 & 1.00 \\
\hline Defence (police, military) & Organization & - & - & 1.11 & 2.73 & - & - & 3.19 & 3.74 & - & - & 0.00 & 2.73 \\
\hline Economists & Organization & - & 1.79 & 2.22 & 2.73 & - & 4.52 & 3.46 & 3.64 & - & 0.00 & 4.42 & 0.85 \\
\hline Businesses, SMEs & Organization & - & - & 2.22 & 2.73 & - & - & 3.88 & 3.04 & - & - & 0.68 & 0.23 \\
\hline $\begin{array}{l}\text { Public members (workers, } \\
\text { households, etc.) }\end{array}$ & Organization & - & 1.79 & 1.11 & 3.64 & - & 0.83 & 3.19 & 3.19 & - & 0.00 & 0.00 & 6.56 \\
\hline Public, religious figures & Organization & - & 1.79 & 3.33 & 1.82 & - & 0.83 & 3.55 & 2.91 & - & 0.00 & 4.57 & 1.00 \\
\hline $\begin{array}{l}\text { Epidemiologists and public } \\
\text { health experts }\end{array}$ & Organization & 3.85 & 3.57 & 2.22 & 2.73 & 6.62 & 4.69 & 3.55 & 3.64 & 0.00 & 0.34 & 0.12 & 1.00 \\
\hline Ministry of Health & Organization & 15.38 & 7.14 & 4.44 & 5.45 & 10.32 & 6.14 & 4.43 & 4.36 & 15.75 & 10.49 & 3.35 & 6.53 \\
\hline
\end{tabular}




\section{DISCUSSION}

This research describes discourses on Covid-19 virus management, actors delivering the discourses, and networks among such discourses for the first 5 months since the virus was discovered (17th November 2019 - 20th April 2020). For these five consecutive months, the actors proposed discourses to have their discourses accommodated as public policy by the government - from a healthy lifestyle, wearing masks, to local quarantine (lockdown). The actors delivered such discourses on many occasions, such as media interviews, social media posts, debates on talk shows, seminars, scientific forums, and many others.

Adopting the framework from Hajer $(1993,1995,2002)$, there is a competition among actors when they fighting for their discourse. A discourse coalition takes place in the process to make the discourses dominant. The actors change or adjust their discourses to other developing discourses. This, for instance, occurred to the government officials and the Ministry of Health. Initially (phase 1), the discourse mostly stated by the Ministry of Health was the need for a healthy lifestyle and improving the immunity. When the discourse on local quarantine (phase 2) was developing, the officials of the Ministry of Health adjusted their discourse by proposing other discourses, such as physical distancing, wearing masks, and isolation (separating the healthy people from the people positively contract the virus). The civil organizations (phase 1 ) initially proposed a discourse on the need for closing borders for entries, particularly from affected countries. Then, in the next phase, there was a discourse adjustment. In phase 2 and so forth, the civil organizations submitted a discourse on local quarantine.

In addition to discourse adjustment, a discourse coalition was also carried out by the actors, namely epidemiologists and public policy experts, by presenting other relevant discourses. These actors initially stated the need for a harsher measure of local quarantine (total lockdown on the movement and activity of the community). Upon realizing that this alternative policy was difficult to be taken by the government, they issued other discourse, namely massive tests and intensive tracking of all people indicated to be virus-positive.

The outcome of such discourse coalition among such actors as shown in this research caused two major discourse clusters. These clusters showed a discourse conflict among existing different discourses (Schon \& Rein, 1994; Muller, 2015). The first cluster consists of the Ministry of Health, the public, central government officials, religious/public figures, and businesses/SMEs. The discourse emerging from this cluster was the moderate Covid-19 case management, such as boosting immunity, healthy lifestyle, wearing masks, physical distancing, etc. The second cluster consists of epidemiologists/public health experts, politicians, public policy experts, and civil organizations. This group consistently voiced the need for the strict measure to contain the spread of the virus, such as local quarantine or massive tests and intensive tracking for people alleged to be virus-positive. Observed from such two clusters, some actors stood in the middle (such as doctors/hospitals, local government officials), in which they sometimes voiced a discourse similar to that of the first cluster and sometimes they proposed a discourse similar to that of the actors in the second group.

How do these developing discourses affect government policy? The policy taken by the government, namely a partial restriction on the activities of the community (PSBB/LargeScale Social Restriction), is a compromise between the discourses desiring moderate virus management (first group) and those desiring harsh measure (second group). The policy on PSBB was issued on 10th April 2020 or more than 1 month since the first positive case was 
found in Indonesia. The delay on this decision is more likely because the government needs to consider various policies and discourses developing in the public.

\section{CONCLUSION}

This research descriptively defines the discourses, actors, and networks among discourses regarding Covid-19 cases in Indonesia for 5 months. During the period, the actors' statements are grouped into 12 discourses.

The results of this study show that a coalition of discourse also occurs in health issues. The study reinforces the findings of Leifeld and Haunss (2011), how actors attempt to present discourse to dominate public conversation. This research shows the efforts of government actors (central government, regional governments, the Ministry of Health) to conduct a coalition between two opposing discourses. These efforts by the government are not entirely successful. This is evident from the discourses raised by the government that were frequently at odds with the discourses proposed by epidemiologists or civil groups. It is alarming because, in matters relating to health, the public is more compliant with health protocols supposing the voice of the government is single (see Nizamani, 2019). The government is also less successful in using communication channels and social media to form a single discourse. This reinforces the previous study conducted by Ika Karlina (2019) regarding the communication of government officials in Indonesia.

A study on the discourse network analysis (DNA) provides theoretical or practical contribution. Theoretically, the DNA research bridges researches on discourse analysis (focus on the content) and network analysis (focus on the actors). DNA combines these two methods by mapping the discourses, actors proposing the discourses, and networks among such discourses. Practically, DNA research is beneficial for the policymakers to map discourses developing in the public.

\section{BIODATA}

Eriyanto is a lecturer at the Department of Communication Science, Universitas Indonesia (UI), Jakarta, Indonesia. Email: eriyanto09@ui.ac.id

Denny Januar Ali is a founder and director of Indonesian Survey Circle / Lingkaran Survei Indonesia (LSI), Jakarta, Indonesia. Email: dennyali46@yahoo.com 


\section{REFERENCES}

Benford, R. D., \& Snow, D. A. (2000). Framing processes and social movements: An overview and assessment. Annual Review of Sociology, 26, 611-639.

Brandes, U., \& Wagner, D. (2004). Visone: Analysis and visualization of social networks. In M. Jünger \& P. Mutzel (Eds.), Graph drawing software (pp. 321-340). Berlin/Heidelberg: Springer.

Breindl, Y. (2013). Discourse networks on state-mandated access blocking in Germany and France. Info, 15(6), 42-62.

Broadbent, J., \& Vaughter, P. (2014). Inter-disciplinary analysis of climate change and society: A network approach. In M. J. Manfredo, J. J. Vaske, A. Rechkemmer, \& E. A. Duke (Eds.), Understanding society and natural resources: Forging new strands of integration across the social sciences (pp. 203-228). Heidelberg/Berlin: Springer.

Buckton, C., Fergie, G., Leifeld, P., \& Hilton, S. (2019). A discourse network analysis of UK newspaper coverage of the "sugar tax" debate before and after the announcement of the Soft Drinks Industry Levy. BMC Public Health, 19(1), 490-514.

Butts, C. C. (2008). A relational event framework for social action. Sociological Methodology, 38(1), 155-200.

Fergie, G., Leifeld, P., Hawkins, B., \& Hilton, S. (2019). Mapping discourse coalitions in the minimum unit pricing for alcohol debate: A discourse network analysis of UK newspaper coverage. Addiction, 114(4), 741-753.

Fisher, D. R., Waggle, J., \& Leifeld, P. (2013). Where does political polarization come from? Locating polarization within the U.S. climate change debate. American Behavioral Scientist, 57(1), 70-92.

Fisher, D. R., Leifeld, P., \& Iwaki, Y. (2013). Mapping the ideological networks of American climate politics. Climatic Change, 116(3), 523-545.

Ghinoi, S., Wesz, V. J. Jr., \& Piras, S. (2018). Political debates and agricultural policies: Discourse coalitions behind the creation of Brazil's Pronaf. Land Use Policy, 76, 68-80.

Ghinoi, S., \& Steiner, B. (2020). The political debate on climate change in Italy: A discourse network analysis. Politics and Governance, 8(2), 215-228.

Girvan, M. \& Newman, M. E. J. (2002). Community structure in social and biological networks. PNAS, 99(12), 7821-7826. https://doi.org/10.1073/pnas.122653799

Golbeck, J. (2013). Analyzing the social web. Waltham, MA: Morgan Kauffman.

Haas, P. M. (1992). Introduction: Epistemic communities and international policy coordination. International Organization, 46(1), 1-35.

Hajer, M. (1993). Discourse coalitions and the institutionalization of practice: The case of acid rain in Britain. In F. Fischer \& J. Forester (Eds.), The argumentative turn in policy analysis and planning (pp. 43-76). Durham, NC: Duke University Press.

Hajer, M. (1995). The politics of environmental discourse: Ecological modernization and the regulation of acid rain. Oxford: Oxford University Press.

Hajer, M. (2002). Discourse analysis and the study of policy making. European Political Science, 2(1), 61-65.

Hajer, M. (2005). Rebuilding ground zero: The politics of performance. Planning Theory \& Practice, 6(4), 445-464.

Heaney, M. T., \& Leifeld, P. (2018). Contributions by interest groups to lobbying coalitions. The Journal of Politics, 80(2), 494-509. 
Ika Karlina Idris. (2018). Government social media in Indonesia: Just another information dissemination tool. Jurnal Komunikasi: Malaysian Journal of Communication, 34(4), 337-356.

Jørgensen, M. \& Phillips, L. (2002). Discourse analysis as theory and method. London: Sage publications.

Kukkonen, A., \& Ylä-Anttila, T. (2020). The science-policy interface as a discourse network: Finland's climate change policy 2002-2015. Politics and Governance, 8(2), 200-214.

Leifeld, P., \& Haunss, S. (2010). A comparison between political claims analysis and discourse network analysis: The case of software patents in the European Union. Max Planck Institute for Research on Collective Goods Bonn, 2010/21.

Leifeld, P., \& Haunss, S. (2012). Political discourse networks and the conflict over software patents in Europe. European Journal of Political Research, 51(3), 382-409.

Leifeld, P., \& Schneider, V. (2012). Information exchange in policy networks. American Journal of Political Science, 53(3), 731-744.

Leifeld, P. (2013). Reconceptualizing major policy change in the advocacy coalition framework: A discourse network analysis of German pension politics. The Policy Studies Journal, 41(1), 169-198.

Leifeld, P. (2017). Discourse network analysis: Policy debates as dynamic networks. In J. N. Victor, A. H. Montgomery \& M. Lubell (Eds.), Oxford handbook of political networks (pp 301-325). New York: Oxford.

Leifeld, P., Gruber, J., \& Bossner, F. R. (2019). Discourse network analyzer manual: Version 2.0-beta24.jar with rDNA 2.1.16. Colchester: University of Essex. Retrieved from https://www.philipleifeld.com/ software/software.html

Leifeld, P. (2020). Policy debates and discourse network analysis: A research agenda. Politics and Governance, 8(2), 180-183.

Linder, S. (1995). Contending discourses in the electric and magnetic fields controversy: The social construction of EMF risk as a public problem. Policy Sciences, 28(2), 209-230.

Muller, A. (2015). Using discourse network analysis to measure discourse coalitions: Towards a formal analysis of political discourse. World Political Science, 11(2), 377404.

Nagel, M., \& Satoh, K. (2018). Protesting iconic megaprojects: A discourse network analysis of the evolution of the conflict over Stuttgart 21. Urban Studies, 56(8), 1681-1700.

Nizamani, F. Q., Ishak, S. Z. A, \& Nizamani, M. Q. (2019). Political factors affecting parents' perceptions on televised polio messages in Sindh, Pakistan: A critical investigation. Jurnal Komunikasi: Malaysian Journal of Communication, 35(3), 300-315.

Olick, J. K., \& Levy, D. (1997). Collective memory and cultural constraint: Holocaust myth and rationality in German politics. American Sociological Review, 62(6), 921-936.

Riffe, D., Lacy, S., Watson, B., \& Fico, F. (2019). Analyzing media messages: Using quantitative content analysis in research (4th ed.). London: Routledge.

Romel, W., Gunawan, R., \& Virgiano, L. J. (2020). The impact of Covid-19 to Indonesia's economic growth. Jakarta: Faculty of Economics and Business Tarumanagara University.

Schon, D. A., \& Rein, M. (1994). Frame reflection. New York, NY: Basic Books.

Steinfeld, N. (2016). The F-campaign: A discourse network analysis of party leaders' campaign statements on Facebook. Israel Affairs, 22(3-4), 743-759.

Waagsaether, K. L., \& Scott, D. (2016). Discourse analysis as a method for understanding the framing of urban governance. South Africa: FRACTAL. 
Wagner, P., \& Payne, D. (2017). Trends, frames and discourse networks: Analysing the coverage of climate change in Irish newspapers. Irish Journal of Sociology, 25(1), 5-28.

Wallaschek, S., Starke, C., \& Brüning, C. (2020). Solidarity in the public sphere: A discourse network analysis of German newspapers (2008-2017). Politics and Governance, 8(2), 257-271.

Wolfsfeld, G., \& Sheafer, T. (2006). Competing actors and the construction of political news: The contest over waves in Israel. Political Communication, 23(3), 333-354.

Yun, S., Ku, D., \& Han, J. (2014). Framing climate change as an economic opportunity in South Korean newspapers. Development and Society, 43(2), 219-238. 